\title{
WHY IS THE DOCTOR IN THE MERRY WIVES OF WINDSOR CALLED CAIUS?
}

\author{
by
}

LORD MCNAIR, Q.c.

JoHn Carus, born in 1510, was, from 1559 to $1573,{ }^{1}$ Master of Gonville and Caius College, which he refounded and re-endowed. His father resided in Norwich but was of Yorkshire origin, and the name is probably Keys or Kees, though it occurs in the college records in ten different spellings: Kees, Keys, Keis, Kesse, Cais, Kaius, Keyse, Cayus, Keysse, Caius. Persons bearing the name of Kayes, Keyes, Kays or Keys, were common, but very few of them moved in the circles in which it was customary to latinize one's name. The D.N.B. records a John Caius who flourished about 1480 and translated a Latin poem into English, and a Thomas Caius or Key, a fellow of All Souls and Master of University College, Oxford, who crossed swords with our John Caius of Cambridge on the relative antiquity of the two universities and died in 1592. Neither of these candidates for representation in The Merry Wives can be regarded as 'starters'.

In 1539 John Caius of Cambridge left England for the purpose of studying medicine in the University of Padua where he graduated M.D., spending five years in Italy, and became a professor. He returned to England in 1545 after making many important medical contacts and examining many manuscripts of Galen and Hippocrates, some of which he was able to bring to England. ${ }^{2} \mathrm{He}$ then developed a leading practice as a physician, became President of the College of Physicians nine times and was appointed physician to Edward VI, Mary and (until 1568) Elizabeth. He died in 1573. It is clear that he was one of the most eminent medical practitioners and scholars in England. ${ }^{3}$

Unless the name in the play was a pure fabrication by Shakespeare, which is almost impossible, it was probably adopted in the hope or belief that it would have a medical association. History does not record any obvious contemporary of Dr. Caius whose position and personality could have suggested the name, but that does not excuse us from investigating its possible sources or explanations.

As we shall see later, the presence of a comic foreign doctor in The Merry Wives can cause no surprise, but the complete incongruity of the Dr. Caius of the play with Dr. Caius of Cambridge calls for some examination of the play and the choice of the name.

\footnotetext{
1 He was succeeded as Master by Dr. Thomas Legge (D.N.B.) 1535-1607, well known as a university actor and producer of plays, author of Richardus Tertius and at least one other play, The Destruction of Jerusalem, and a Master in Chancery; he was a close friend of Dr. Caius who nominated him as his successor in pursuance of a power conferred upon him by the Fellows.

Including probably some of the MSS. now in the Gonville and Caius College Library.

3 See D.N.B. and Venn, Biographical History of Gonville and Caius College (referred to hereafter as 'Venn') iii, pp. 30-63. Caius was English in birth and in speech, but in accordance with the prevailing habit of a scholar with an international background or reputation he latinized his name.
} 
It is useful in the elucidation of this problem to divide it into three questions: (i) Why did Shakespeare put a comic foreign doctor into The Merry Wives? (ii) Why was the comic doctor French? and (iii) Why did he call his comic foreign doctor 'Dr. Carus'?

\section{(i) WHY DID HE PUT A COMIC FOREIGN DOCTOR INTO The Merry Wives?}

The short answer to this question is that the comic foreign doctor was a stock figure in contemporary comedy, and that in the climate of the time it was a most natural thing to do. If we have a look at some of the physicians who figure in other plays, both before and after The Merry Wives, we shall see what the audience would expect." According to most of the authorities, the play was written in great haste in response to Queen Elizabeth's command. Dover Wilson examines this tradition, which seems to have first found its way into print in 1702, and accepts it. After referring to the deer-stealing episode, attributed rightly or wrongly to Shakespeare in his youth, he continues: ${ }^{5}$

'The other tradition-that Shakespeare wrote The Merry Wives under royal command and produced it in a fortnight or so-is obviously of far greater, indeed of capital, importance to the critic and the textual editor; and therefore we make it our starting-point.' Indeed, he embraces it with open arms as the best explanation of the puzzles and confusion to which the text gives rise. 'The plot, when analysed, almost resolves itself into confusion: yet the confusion can be accounted for-with the help of this anecdote.'

'What happened [we suggest] was this. The Company, harried by this violent order, hunted out of their repertory a play, The Jealous Comedy, of which [be it admitted] we know nothing save that they had performed it on January 5, 1593; and turned Shakespeare upon it to work it up."?

The Merry Wives was first performed, in Dover Wilson's opinion, 8 'almost certainly at Windsor itself somewhere about the years $1598-1600$ '. Professor Bradbrook puts the date rather later-1600-1601. The first quarto to be published is dated 1602 and tells us that the text is 'As it hath bene divers times acted by the right Honorable my Lord Chamberlaines servants. Both before her Maiestie, and else-where'. ${ }^{\circ}$ It is

\footnotetext{
' It is perhaps worth mentioning that in the Mummers' Play and in other folk-plays there is usually a Doctor, often comic, often with a man, and there is frequently a combat: Chambers, The English Folkplay (1933), and the Medieval Stage, i (index Doctor). Dover Wilson (Merry Wives, p. xxxiii) refers to a note by Steevens in the 1803 edition of Dr. Johnson's Shakespeare upon the story of a 'Foole of Winsor' in Jack of Dover's Quest of Enquirie (1604) (perhaps a re-publication), which begins as follows: 'Upon a time there was in Winsor ... a certain simple outlandishe [foreign] doctor of phisicke belonging to the deane, who on a day being at Eton college' was cheeked by a schoolboy. Although Dr. Caius, as a Physician to Mary, Edward VI and (for a short time) Elizabeth, must have visited Windsor from time to time, this incident can hardly refer to him. The comic doctor was also a popular figure in the Commedia del l'arte improvissa.

5 Cambridge text p. viii; this text of his Merry Wives is referred to throughout.

- p. IX. Dover Wilson, who was an honorary fellow of Gonville and Caius College, has said by way of caveat in some other connection 'Shakespeare does not do these things by accident'. This means that every effort must be made to make sense of everything that Shakespeare wrote, but if there is any play in which an accident could easily occur it is The Merry Wives.

' Baldwin, Organization and Personnel of the Shakespearean Company (1927), p. 270, is so confident that The Jealous Comedy (1592 winter) is an early form of The Merry Wives, that in his list of characters (facing p. 229) occurring in The Jealous Comedy we find nearly all the characters of The Merry Wives except Dr. Caius. I do not know what is the source of, or authority for, this view.

p. XII.

- p. XI.
} 


\section{Why is the Doctor in 'The Merry Wives of Windsor' called Caius?}

known as a 'Bad Quarto', and indeed it is very bad. It is so bad and so much shorter than the Folio of 1623 that no commentator could 'base a text on it'. Dover Wilson ${ }^{10}$ is forced to make "the supposition that the "copy" for the Folio text was made by stringing together players' parts with the aid of the theatrical "plot"11 of the play.' He continues ${ }^{12}$

'Parts of it [the "copy" for the Quarto] were "reported", that is to say, written out from memory, by a pirate-actor, who, as Greg has shown, played the Host in the final version.'

Moreover, quite apart from these impediments to an accurate knowledge of what the actors actually said, we must remember that the play was 'a rush job', and we cannot expect that, even if a good text was available, it would be tidy and logical and free from confusion. Neither the Bad Quarto of 1602 nor the Folio of 1623 contains a list of dramatis personae, which is further evidence of the hasty compilation of the play.

Chambers writes:18 'The play was written in haste and its structure suffered', and ${ }^{14}$ 'I think we may accept the story of Elizabeth's request, and suppose it motived by Shakespeare's failure to redeem in Henry $V$ the promise of a reintroduction of Falstaff suggested by the Epilogue to 2 Henry IV', a very charming passage which reads like an impromptu speech, and concludes thus:

'One word more, I beseech you. If you be not too much cloyed with fat meat, our humble author will continue the story, with Sir John in it, and make you merry with fair Katharine of France; where (for any thing I know) Falstaff shall die of a sweat, unless already a' be killed with your hard opinions; for Oldcastle ${ }^{15}$ died a martyr, and this is not the man . . My tongue is weary, when my legs ${ }^{16}$ are too, I will bid you good night.'

It is not fanciful to suggest that there are certain special factors operating in the construction of The Merry Wives, which have influenced its content. In the first place it was a court play, ${ }^{17}$ written in great haste for a particular occasion. Not only for a particular occasion but for a particular audience-the Queen and her more intimate entourage, her ministers and courtiers, and her women, the kind of people with whom she was at home and in the closest daily association. It is almost in the nature of 'private theatricals' arranged for the entertainment of a house party, assembled in a great man's house for the celebration of Christmas or some other feast. If Shakespeare, the creator of Falstaff, was instructed to prepare the dramatic

\footnotetext{
10 The latest serious study of The Merry Wives known to me is a book by an American scholar William Green, Merry Wives of Windsor (1962) which is a statement of the view that it is a Garter play, commissioned for the purpose of the Feast of the Order of the Garter at Windsor in April 1597. In his opinion the company were given some three or four weeks' notice that a play would be required for this purpose, and of that period the author might have had two weeks allowed him for the actual composition. So far as concerns the place of The Merry Wives in the sequence of the Falstaff plays, he regards it as 'an island unto itself in the midst of the history plays' (p. 177).

11 By 'plot' I understand him to mean the plan or scheme of the play, something akin to the scenario of the Commedia dell' arte improvissa, to which I shall refer later.

12 p. 95

18 William Shakespeare, i, p. 432.

14 Ibid., p. 434

15 Thereby hangs a very different story which I shall not examine.

${ }_{16}$ The Epilogue is believed to have been delivered by a dancer.

17 If not in the technical sense.
} 
entertainment, it is reasonable to suppose that, working under great pressure of time, he did not attempt a completely new production but felt free to draw upon the current stories and traditions of the London stage and the jokes of the court and then, unhampered by dramatic orthodoxy, to fuse them together, as only he could do, to produce a most amusing evening. One illustration of the essentially local and domestic character of the play is the Mümpgellart business. ${ }^{18}$ This German Count on his visit to Reading, Windsor and Eton College in 1592 or 1593 made himself so ridiculous that he was remembered for some years later particularly in the court circle. The joke was wearing a bit thin in 1597 or 1598 when he applied, and was approved by the Queen, for the Garter, but, as Dover Wilson ${ }^{19}$ points out, the business was stale 'in 1602, and allusion to it only survives by accident in the word "garmombles"; and then King James comes to the throne, and our play is revived for a court performance in 1604, by which time it is staler yet. So out goes the last trace of "cozen garmombles" to make room for an indefinite Duke de Iaminie and a train of "Cozen-Iermans" . . ' It is doubtful whether the Mümpgellart business would have lasted so long if this had not been a court play. It is unlikely that it would have afforded much amusement to the general public so many years after it happened; for a court audience the Garter installation of 1597 would act as a reminder of an old joke. This incident is a good example of the 'topical and personal allusions' likely to occur in a play which is written for a particular audience in a particular place-'almost certainly at Windsor'. There are also other 'topical and personal allusions'.

\section{(ii) WHY WAS THE COMIC DOCTOR FRENCH?}

The short answer is that in comedies of that time the comic doctor was usually either Italian or French, and there was a well-known play called The French Doctor. I shall give instances of a number of comic doctors and then pay particular attention to that play.

In view of the evidence of the influence of the Italian drama, ${ }^{20}$ in particular comedy, upon the English dramatists including Shakespeare, it should be noted that the medical doctor played a significant part on that stage. Adolphus Ward, ${ }^{21}$ writing on the masked comedy of Italy, says that 'The masked characters, each of which spoke the dialect of the place he represented, were (according to Baretti) Pantalone, a Venetian merchant; Dottore, ${ }^{22}$ a Bolognese physician; Spaviento, a Neapolitan braggadocio; Pulcinella, a wag of Apulia; Giangurgulo and Coviello, clowns of Calabria; Gelfomino, a Roman beau; Brighella, a Ferrarese pimp; and Arlecchino, a blundering servant of Bergamo'; and there were others. The last-named has survived in England,

\footnotetext{
1s See Crofts, Shakespeare and the Post Horses (1937).

10 At p. xxi.

30 Lea, Italian Popular Comedy, ch. VI 'The Commedia dell' Arte and the English Stage', and pp.431-55, 'Traces in Shakespearean Drama'.

i1 Encyclopaedia Britannica (11th ed.), Drama, vol VIII, p. 505, n.1. 'Mask' means not only the traditional covering of the actor's face but 'the abstract of the behaviour of innumerable' actors associated with a particular traditional character. Masked doctors 'are not people but personages': Lea, op cit., p. 17.

${ }_{22}$ Professor Bradbrook has drawn my attention to Haughton's Englishmen for my Money (1598) (also called $A$ Woman Will Have her Will) as an example of the influence of the Italian comic dottore (see Lea, op. cit., pp. 415-19).
} 


\section{Why is the Doctor in 'The Merry Wives of Windsor' called Caius?}

or at any rate did when I went to my first pantomime. Dr. Gratiano ${ }^{23}$ of Bologna was a well-known mask, but it seems that under this and other names such as 'Grazian', 'Graziano', 'Graciano', he was normally a lawyer, with a possible reminiscence of Gratian of the Decretals, but he could be a medical doctor ${ }^{24}$ and among his characteristics were his loquacity and his ability to speak a number of dialects. Medical doctors under other names were common.

The Rare Triumphs of Love and Fortune ${ }^{25}$, by an unknown author, was 'Plaide before the Queenes Most Excellent Maiestie [between Christmas 1581 and February 1582, according to J. P. Collier] wherein are manye fine Conceites with great delight', and published in London in 1589. The characters are a mixture of gods and goddesses (Venus being prominent for obvious reasons) and mortals. One, Bomelio, enters 'like a counterfeit Physician', and abandoning his quite orthodox English speech, speaks a jumble of Italian, French and broken English: 'Bien venu, chi diue ve mi nou intendite signeur, no' . . .'Dio vou salvi, signore, a voutre gratio pavero mouchato' . . 'Monsieur, par ma foy, am one have the grand knowledge in the skience of fiskick.'

'Can make dem hole have been all life sick;

Can make to $\operatorname{seco}^{28}$ see, and te dumb speak;

Can make te lame go, and be ne'er so weak.'

The Wisdome of Doctor Dodypoll, ${ }^{27}$ a rare play, was printed in 1600 'As it hath bene sundrie times Acted by the Children of Powles'. Dr. Dodypoll and a merchant are wooing Cornelia, described by Bullen as 'an ill-favoured virgin', and seek to outdo one another in protestations of love. But the doctor has 'promist ... a drug' to another suitor, who enquires: 'are you sure it will worke the effect?' to which the doctor replies: 'Me be sure? by garr she no sooner drinke but shee hang your neck about; she stroake your beard; she nippe you sheeke; she busse your lippe, by garr.'

He too has a man and a house-keeper, but their parts are inconspicuous.

There are some curious resemblances between Doctor Dodypoll and Shakespeare's Dr. Caius. Their favourite oath is 'begar' or 'by garr' or 'be garr'-in one form or another. Dr. Dodypoll uses as a variant 'garrs blur', which may be 'god's blood'. They both have a man and what appears to be a housekeeper. They are both suitors for the hand of a lady, though the ladies differ very much. Both boast of their distinguished patients. Dodypoll speaks of 'de grand patient', and Dr. Caius promises mine Host that he will 'procure-a you de good guest, de earl, de knight, de lords, de gentlemen, my patients'. The same trick is played on both of them. Mistress

${ }^{22}$ Lea, op. cit., pp. 25-41, and 596 where there is a medical doctor called Galeno; and Winifred Smith, Commedia dell' Arte, index. If it be true that the Commedia del' Arte improvissa had an influence upon English comedy, there could be no better opportunity for that influence than a hasty job like The Merry Wives. Shakespeare would concentrate upon Falstaff and the merry wives, but he could be pardoned if he gave considerable latitude, on the occasion of the first performance, to Dr. Caius and Sir Hugh Evans to make their own parts. See Professor Bradbrook on 'Oral Tradition' in Growth and Structure of Elizabethan Comedy, pp. 31, 32.

${ }^{24}$ Lea, op. cit., p.33. The main point of the doctor mask was that the doctor should be a silly old fool.

${ }^{25}$ Hazlitt (Dodsley's), Old English Plays, 4th ed. (1874) vol. VI. pp. 143, $200,201$.

28 to $\operatorname{ceco}=$ the blind.

${ }_{27}$ Chambers, Elizabethan Stage, iii, 136; iv, 54; it is printed in Bullen's Collection of Old English Plays, vol. III: p. 104. O.E.D. describes Dodypoll as 'a stupid person, blockhead, fool,' According to Steevens, the play was composed before 1596.

H. C. Hart, Arden edition of The Merry Wives, pp. LIX-LX, refers to Nashe's Terrors of the Night (1954), containing an impostor who 'speaks nothing but broken English like a French Doctor, pretending to have forgotten his naturall tung by travell'. 
Quickly says to Dr. Caius: 'Sir, the maid loves you, and all shall be well'. The merchant seeks out Dr. Dodypoll to tell him that 'the marriage which we thought made even now, between Earle Cassimere and Cornelia, was but a jest only to drawe you to marry her, for she doth exceedinglie dote upon you'. ${ }^{28}$ While Mistress Quickly predicts that if her master finds anybody in the house 'here will be an old abusing of God's patience and the king's English', the merchant says of Dr. Dodypoll: 'Ile to the Courte after him, and see how he abuses the Duke's patience.'29

In 1592 Dr. Legge, who has been referred to above, ${ }^{30}$ sat in the High Court of Delegates, together with his friend Dr. Swale ${ }^{31}$ and two other doctors, on appeal from the Court of Arches, in a case concerning the validity of the marriage of a certain Dr. John Milward to a young lady. It appears from Sisson's Lost Plays of Shakespeare's Age that this was a cause celebre, which lasted for many years in many courts, both lay and ecclesiastical. Judgment was given by Dr. Legge and his colleagues as late as 20 February 1602 , but that did not conclude the litigation. The case attracted much public attention, for Dr. Milward ${ }^{32}$ was 'the Preacher at Christ Church, a sober and judicious man of some thirty-five years of age [in or about 1594] and a Doctor of Divinity' of the University of Oxford. One of the questions in issue was the validity of the young lady's alleged betrothal to two or more other suitors. Her fate would be of no interest to us were it not for the fact that George Chapman, one of the most prolific of dramatists, based a play, The Old Joiner of Aldgate ${ }^{33}$ upon her story. This play was acted by the Children of St. Paul's in February 1603 , and then disappeared for ever. Sisson, after studying the voluminous legal documents which have survived, has been able to reconstruct the play, in which he makes out Dr. Milward to be the traditional French Doctor. 'As for the French Doctor, there can be no manner of question but that Milward came on the stage, a pompous Dr. Caius, speaking broken French, in this grotesque disguise. ${ }^{34}$ Thus Chapman's lost play affords further evidence of the contemporary popularity of a French Doctor, and it will be noted that Dr. Milward in the play, like Dr. Caius in The Merry Wives, has a fancy for a girl young enough to be his daughter.

In The Wit of a Woman, ${ }^{85}$ an anonymous 'prose comedy with Italian names', produced in or about 1604, there is an old physician, Nemo by name, who suffers from 'this disease called love'. Miss Lea ${ }^{36}$ says of it: 'There is no need to ransack Italian fiction for the source of this comedy which gives us the clearest instance of the influence of the Commedia dell'arte'. She cites ${ }^{37}$ Thomas Heywood, who, in the Apology for Actors, proposes 'to omit all the Doctors, Zawnies, Pantaloones, Harlakeenes, in which the French, but especially the Italians, have been excellent'.

Among post-Merry Wives' plays should be mentioned The Wonder of a Kingdom, of which Chambers writes: : $^{38}$ 'printed as Dekker's (q.v.) in 1636, but probably identical

28 Old English Plays, vol. vi, p. 151.

20 Ibid., p. 152.

31 Fellow and Tutor of Gonville and Caius College.

32 D.N.B. 1556-1609. He was a B.A. of St. John's College, Cambridge.

as Not mentioned in Index of Plays in Chambers, Elizabethan Stage; Sisson, Lost Plays of Shakespeare's Age, ch.II.

"Sisson, op. cit., p. 74.

so Chambers, Elizabethan Stage, iv. 54.

36 Italian Popular Comedy, pp. 412-415.

s8 Chambers, Elizabethan Stage, iii 288, 299; Bowers, Dramatic Works of Thomas Dekker, vol. III. 
with Come See a Wonder, licenced by Herbert as [John] Day's in 1623'. It seems to have been acted in 1623, and it is just possible 'that the original play was The Mack, produced by the Admiral's on 21 Feb. 1595'. Here the French doctor is not a real physician but one Angelo Lotti, a lover who counterfeits a French doctor for the purpose of obtaining access to his mistress Fiametta without the consent of her father, the Duke of Florence. Like all good French doctors, Angelo has 'his man', by name Baptista, who calls himself 'a Doctours-man'. Fiametta is ill or is shamming illness. Baptista counsels Angelo thus:

'i'st such a matter

For you then to put on a Doctours-gowne,

And his flat velvet-Cap, and speake the gibbering

Of an Apothecary.'

The Duke is in great distress and would give 'halfe my Duke-dome for her health'. A courtier tells him:

'There's a French-man come to court,

A profest Doctour, that has seen the Princesse,

And will on her recovery pawne his life,'

whereupon 'Enter Angelo like a Doctour, Baptista, his man', who are welcomed by the Duke. Angelo proceeds to give his diagnosis, interlarding his remarks with 'begar' and 'begor' in the approved manner.

It was usual to give a doctor a name which would have been called an outlandish name, if he received a name at all. There were a number of foreign doctors practising in England in Shakespeare's time and, having regard to the reputation of certain notable foreign schools of medicine, particularly in Italy, it may have been an advantage to a practitioner to have a foreign, or at any rate an unusual, name. The doctors in Macbeth and King Lear have no name; in Cymbeline the physician is called Cornelius, and in Pericles Cerimon; while in Henry VIII Dr. Butts of Gonville Hall is allowed to retain his own name. In addition to Shakespeare we find his contemporaries following the same practice. Jonson calles his doctors in The Staple of Newes Almanach and in The Magnetick Lady Rut, while in Hymenaeus the boastful physician is called Pantomagus, which is not surprising in view of its Italian origin. In The Wit of a Woman the doctor is called Nemo, and, rather later, the doctor in The Changeling (1622) by Middleton and Rowley is called Alibius; nor can Benedict in The Honest Whore and Theodore in the Second Part of the Return from Parnassus be regarded as typically English names. In view of this practice in the matter of names we should err if we were to conclude that Dr. Caius of The Merry Wives must be a foreigner: moreover, it was common for a scholar of the standing of Dr. Caius to latinize his name. ${ }^{39}$

Shakespeare's physicians have been discussed by R. R. Simpson in a book entitled Shakespeare and Medicine (1959). I draw particular attention to chapters $\mathrm{v}$ and vi on 'Shakespeare's Doctors' and the 'Influence of John Hall' respectively. Simpson has examined 'seven medical characters', including Dr. Caius, occurring in the plays, the others being the physician in King Lear, the two doctors in Macbeth, Cerimon in

'9 Much interesting information about the medical profession will be found in Shakespeare's England, ch. xiv. 
Pericles, Cornelius in Cymbeline, Butts ${ }^{40}$ of Gonville Hall in Henry VIII; and there is a deceased doctor-Gerard de Narbon in All's Well. He remarks (p. 71) that 'it may, or may not, be of some significance that no doctor appears in any of the plays until about the time when John Hall, Shakespeare's son-in-law settled in Stratford'-in or about $1600 .{ }^{41}$ Excluding Dr. Caius who, in Simpson's words, 'is not presented as a doctor but rather as a buffoon', the general impression given by this book is that they were a good lot of respectable and conscientious professional men and that Shakespeare had a high opinion of their profession.

There was no need to introduce any doctor into The Merry Wives except for the purpose of contributing to the fooling, with the result that the play contains many medical allusions. Putting a comic doctor into a comedy verging on farce was most natural in the dramatic climate of the time and was indeed no innovation. What is, however, legitimate matter for surprise is that this comic doctor should be called 'Dr. Caius', and this will be explored later.

The French Doctor. Not only is there ample evidence of the presence of foreign doctors in contemporary plays but we can go further and say that the doctors were usually French, and that in the last decade of the sixteenth century the Admiral's men had in their repertory a lost play entitled The French Doctor, ${ }^{42}$ which demands our close attention. It was played on at least fourteen occasions between 18 November 1594 and 9 November 1596, both inclusive. The following is an extract from the comment by Greg, the editor of volume ii of Henslowe's Diary:43

'(a) Performed by the Admiral's men, as an old play, 18 (19) October 1594, and thence till 9 November 1596, in all 14 performances. (b) Bought on behalf of the Admiral's men, of [i.e. from] Alleyn, 18 January 1601/2, together with two other plays, for $£ 6$.' [The two other plays are "the massaker of france" and "the nutte" ("Crack me this Nut").]

Fourteen times in two years does not seem much to us, but at that date it was rare for a play to have a long life; the total probable audience was small and soon exhausted. Henslowe's Diary was again edited (in 1961) by Foakes and Rickett, and the result of the count is the same.

What the French Doctor did and why he was amusing, we do not know, but the popular dislike of foreign physicians was growing, and it is always easy to make a foreigner on the stage look a fool. So we do not know how much The Merry Wives may owe to The French Doctor. But it is evident that the latter play contained some element of character in common with, or suggesting a resemblance to, The Merry Wives. For when The Merry Wives had been 'divers times Acted by the right

${ }^{10}$ See Venn, i. p. 17 and D.N.B.-a close friend of Dr. Caius and Physician to Henry VIII: and see above, p. 317 .

11 See later p. 328 as to possible consultation with John Hall.

12 Chambers, Elizabethan Stage, ii, 146, 180; iii, 301 where he mentions among his Lost and Doubtful Plays a play called 'The Jew of Venice' 'entered as a play by Dekker in the Stationers Register on 9 Sept. 1653', in which 'a personage disguises himself as a French doctor, which leads to the conjectural identification of its English original both with The Venetian Comedy produced by the Admiral's on 27 Aug. 1594 and with The French Doctor performed by the same men on 19 Oct. 1594 and later dates and bought by them from Alleyn in $1602 \ldots$

'3 Greg, Henslowe's Diary, vol II p. 170 - see also index; Foakes and Rickett, Henslowe's Diary, 1961. Having regard to the dates it is unlikely that the French Doctor in this play can have been called Lopez. The real Dr. Lopez was hung in June 1594 (see later p. 333). 


\section{Why is the Doctor in 'The Merry Wives of Windsor' called Caius?}

Honourable my Lord Chamberlaines servants. Both before her Majestie and elsewhere', two interesting things took place-and on the same day.

The first is the purchase from Edward Alleyn 'on behalf of the Admiral's men' of the play called The French Doctor for the sum of two pounds on 18 January, 1601/2, thus making the Admiral's men the owner of this play. Alleyn was the owner of many plays.

The second thing is described in the Register of the Stationers Company ${ }^{44}$ as follows:

\section{Januarij [1602]}

John Busby. Entred for his copie under the hand of master Seton A booke called An excellent and pleasant conceited commedie of Sir John Ffaulstof and the merry wyves of Windesor vjd. Arthure Johnson. Entred for his Copye by assignment from John Busbye. A booke Called an excellent and pleasant conceyted Comedie of John FFaulstafe and the merye wyves of Windsor, vjd."s

[Footnote by editor. 'It is quite clear that the Merry Wives of Windsor was printed by J. Busby before this date, but not entered in the Registers until he came to assign it to A. Johnson. See the similar case of $K$ ing Lear at $p$. 289.]

Thus after The Merry Wives had been performed 'divers times by my Lord Chamberlaines servants. Both before Her Majestie and elsewhere', that Company realized that it was worth while putting it into their permanent repertory and establishing their title to it by placing it on the Register of the Stationers Company. What can have induced 'the Admiral's men' on the same day to buy from Alleyn The French Doctor which apparently had not been performed since 9 November 1596 ? Professor Bradbrook has (privately) suggested that the Admiral's men may have got wind of the fact that their rivals, the Lord Chamberlain's Company, had got a play-The Merry Wives-which contained an amusing French-speaking doctor and, not knowing the degree of his resemblance to their own French Doctor of the play of 1594, they prudently and promptly took action to protect themselves by buying Alleyn's French Doctor from him. This would be understandable although Alleyn was the leading member of the Admiral's men; he might not remain a member, and, in fact, he was rapidly developing other and different interests. The fact that the purchase of The French Doctor and the registration of The Merry Wives took place on the same day suggests that there was a connection between these two events, and that news of the Chamberlain's new play had been leaked to the Admiral's men.

So much for the ownership and stage history of The French Doctor. Can we find anything as to its content?

Act I, Scene 4, of the Second Part of The Return from Parnassus, ${ }^{48}$ opens with

4 E. Arber, Transcript of the Stationers Company (1554-1640 A.D.) III, 78; and see Greg, Bibliography of the English Printed Drama, vol. 1 (1939), pp. 186 etc. The Stationers Company was incorporated in 1556. 'To this company the Tudors entrusted the general supervision of the trades of printing, binding, publishing, and dealing in books'; Holdsworth, History of English Law, vi, p. 363.

'It appears that as a result of this transaction Arthur Johnson thereafter owned or at any rate controlled The Merry Wives: see Greg, Shakespeare's First Folio (1955) pp. 12, 14, 65, 68; on p. 65 Greg writes as follows:-

'Sir John Falstaff and the Merry Wives of Windsor entered to John Busby (the elder), and immediately re-entered, by assignment from Busby, to Arthur Johnson, 18 January 1602.

Printed (in a bad text) by T(homas) C(reede) for Arthur Johnson, 1602.

Printed "for Arthur Johnson", but actually by William Jaggard for Thomas Pavier, 1619.

Probably printed with Johnson's consent. Johnson's title to the printed version was sound.'

is Edited by Leishman, The Three Parnassus Plays (1949). 
Philomusus in a 'Phisitians habite, Studioso like [that is, counterfeiting] his man, a patient'. The two students are badly down in their luck and are becoming desperate. One of them, Philomusus, says that

'And it's as good to starve mongst English swine,

As in a forraine land to begge and pine'

and after some lines expressing their common desperation Philomusus remarks (line 17):

'But letts leaue this capping of rimes, Studioso, and follow our late devise [my italics], that wee may maintaine our heads in cappes, our bellyes in provender, and our backs in saddle and bridle...

And first my plot ${ }^{77}$ for playing the French Doctor [my italics], that shall hold: our lodging stands here fittlye in Shooe Lane, for if our commings in be not the better, London may shortely throw an old shooe after us, and with those shredds of French, that we gathered up in our hostes house in Paris, wee'll gull the world, that hath in estimation forraine Phisitians, and if any of the hidebound brethren of Cambridge or Oxford, or any of those Stigmatike Masters of Arts, that abused us in times past, leave their owne Phisitians, and become our patients, wee'l alter quite the stile of them, for they shall never hereafter write, your Lordships most bounden, but, your Lordships most laxative.'

Act II, Scene I, shews the plot or 'devise' in operation, namely, for an English physician to pretend that he is French and thus circumvent the current English preference for 'forraine Phisitians'. Philomusus has now become Theodore, a French physician, speaking a medley of French, Latin and English. His man is called Jaques and his patient is a Burgesse and a 'publike Magistrate', who feels called upon to explain why he is not content with an English doctor:

'I hope master Doctor you have a care of the countryes officer, I tell you I durst not have trusted myselfe with every phisition, and yet I am not afraide for my selfe, but [that] I would not deprive the towne of so carefull a magistrate. ${ }^{98}$

Dr. Caius of The Merry Wives' is not just a doctor. He is 'the French Doctor', and when the audience very early in the play hear Sir Hugh Evans say to Slender's man:

'Hark you Simple, pray you beare this letter to Doctor Cayus house, the French doctor. He is twell vp along the street, and enquire of his house and for one mistris Quickly, his woman, or his try nurse ...', and when Mistress Quickly (Act I, Sc. 4.92,

i7 Normally in an Elizabethan context 'plot' would mean either the card available to the actors and the prompter, indicating the separate scenes, the relevant properties, the entries and the exits of the actor, etc. (see Percy Simpson, Shakespeare's England, ii, p. 265), or the whole plan or scheme or outline of a play more akin to, but not identical with, the Italian scenario. I suggest that here 'my plot' means a device, a trick, which is described in Act II scene I, where we find Theodore the French Doctor and his man Jaques fooling in French and collecting a fee from an unlucky 'Burgesse'.

18 The Second Part of the Return from Parnassus, line 542 of Leishman's edition. Act II, Scene 5, is mainly devoted to a dialogue between Academico and Amoretto concerning dogs and hunting and is highly technical or mock-technical, and reminiscent, as Leishman points out, of Dr. Caius' book, 'Of Englishe Dogges', written in Latin, translated into English by Abraham Fleming and published in 1576.

Lines 547-9 of Act II, Scene 1, reflect the English doctor's natural dislike of the 'forraine physitian':

'Theodore. O Monsieur I have a singular care of your valetudo: it is requisite that the French Phisition be learned and careful, your Anglish velvet cap is malignant and envious.'

"I shall not attempt to specify the various texts from which these quotations come. In the opinion of T. W. Baldwin, Organization and Personnel of the Shakespeare Company, p. 274 and a list preceding p. 229, the name of the actor taking the part of Dr. Caius was Alexander Cooke. 


\section{Why is the Doctor in 'The Merry Wives of Windsor' called Caius?}

in the Folio text) says: 'and the very yea and the no is, the French doctor, my masterI may call him my master, look you, for I keep his house; and I wash, wring, brew, bake, scour, dress meat and drink, make the beds, and do all myself -' the audience at once recognizes the references to a popular comic figure and know they are going to have some fun.

Dr. Caius satisfies their expectations:

'I, you be John Rugbie, and you be Iack Rugby

Goe run vp met your heeles, and bring away

De oyntment in de vindoe present':

'Vat is you sing? I do not like dese toys: pray you go and vetch me in my closet une boite en verde, a box, a green-a box. Do intend vat I speak? . . . ma foi, il fait fort chaud. Je m'en vais à la cour-la grande affaire.'

Thus his foreign origin becomes obvious, and the more experienced members of the audience recognize their old favourite, the French Doctor. This recognition is confirmed when in Act II, Scene 3, the Host addresses Dr. Caius as 'my francoyes' in the Quarto and 'my Francisco' in the Folio, and Page describes him as 'the renowned French physician'.

Did the French Doctor have a name? If so, was it 'Dr. Caius', or was that name attached to him after his reincarnation in The Merry Wives? Dr. Caius of the latter play was French enough to be a French doctor. He was as French as a man could reasonably be on an English stage. His 'Frenchness' is insisted on. In Act I, scene 4, his house-keeper, Mrs. Quickly, describes him as 'the French doctor, my master', and in Act III, Scene I, Master Page refers to him 'as the renowned French physician'; in Act III, Scene I, the Host refers to him as French, and in Act II, Scene I, calls him 'my Francisco'. In addition to his broken English he uses a number of French expressions, je m'en vais d la cour-la grande affaire, and words, baillez me some paper, un garçon and un paysan, $O$ diable, etc. (A man usually swears in his native tongue.) In Act III, Scene 3, when Evans, apparently in anticipation of the forthcoming duel, speaks of 'fery fantastical humours and jealousies', Dr. Caius replies 'By gar, 'tis no the fashion of France; it is not jealous in France'.

(iii) WHY DID HE CALL HIS COMIC FOREIGN DOCTOR 'DR. CAIUS'?

Before attempting to answer this question I venture to digress somewhat in order to refer to an event in the professional career of Dr. Caius which attracted much attention from laymen, namely, his popular treatise in English on 'the Sweat' or Sweating-sickness. I do not suggest that his reputation as the leading authority on 'the Sweat' was the sole or principal cause of Shakespeare becoming aware of him, but I have little doubt that Shakespeare connected him with 'the Sweat', and I shall give my reasons. Moreover, quite apart from the play, 'the Sweat' is an interesting incident in our medical history and illustrates the merits of Dr. Caius ${ }^{50}$ as a clinician.

${ }^{50}$ In 1552 he published a book or text in English entitled A boke or counseill of John Caius against the disease commonly called the Sweat or Sweatying Sicknesse, followed in 1555 by a longer and more technical book in Latin, De ephemera britannica, intended for the medical profession, both printed in Venn's Works of John Caius. The fact that he should publish the very practical 'Counseill' in English for the layman seems to me to illustrate the extreme sparseness of medical practitioners at that time, at any rate outside large towns. On the contribution of Dr. Caius to the organization of his profession, see G. N. Clark, A History of the Royal College of Physicians (1964) ch. VII. 'Dr. Caius and Resolute Action'. 


\section{Lord McNair, Q.C.}

When a Victorian novelist had exhausted the usefulness of a character he or she 'went into a decline' or 'died of consumption'. When Sir John Falstaff had served Shakespeare, and served him well, his fate was to 'die of a sweat', a disease well known to the public, notably and conveniently expeditious in its operation, and, as we shall see, most appropriate to Falstaff's figure and habits. In the charming Epilogue to 2 Henry IV, the manner of the old man's end was foretold:-

'If you be not too much cloyed with fat meat, our humble author will continue the story, with Sir John in it, and make you merry with Fair Katharine of France; where (for anything I know) Falstaff shall die of a sweat, unless already a' be killed with your hard opinions'.

I believe that Shakespeare's only other reference to 'the Sweat' is attributed to Mistress Overdone in Measure for Measure, Act 1, Sc. 2: 'What with the war, what with the sweat, what with the gallows, and what with poverty, I am custom-shrunk', upon which it is stated by Doran in Shakespeare's England, i, p. 435, note 2, that the word 'sweat' 'clearly signifies a deadly epidemic, not an endemic disease.'

The Hostess, our old friend Mrs. Quickly, has abandoned the Boar's Head tavern in Eastcheap and married Pistol, and they are now the host and hostess of the inn where Falstaff lodges. She has described the manner of his death in a memorable passage in Henry V, Act II, Scenes 1 and 3, which will be found below.

Dover Wilson in a note on p. 136 of his Henry $V$, on the words 'quotidian tertian'51 which occur in this passage, says that the Hostess 'refers apparently, confusedly, to ague, though some think that the "sweating-sickness" is implied', for which see Creighton, ${ }^{52}$ History of Epidemics in Britain (i. 237, ii. 310, 311, n.1.). If the latter, Shakespeare may be slyly fulfilling, in part, the promise of the Epilogue to 2 Henry $I V$ : 'where (for any thing I know) Falstaff shall die of a sweat'. But neither ague nor 'sweat' has anything to do with a broken heart-('fracted and corroborate').

Creighton also contributed to Blackwood's Magazine ${ }^{53}$ in 1889 an article entitled Falstaff's Deathbed. Its main object was to discuss the well-known controversy on the question whether in describing the manner of Falstaff's death Shakespeare wrote

'for his nose was as sharp as a pen, and a' babbled of green fields'

or

'for his nose was as sharp as a pen on a table of green fields' (that is, covered with green baize cloth).

I do not propose to discuss this controversy, ${ }^{54}$ beyond saying that some lovers of the old rascal cannot fail to be attracted by the notion that his dying thoughts should revert to the days of his rural innocence, as I believe happens to many of us. In the course of this article Creighton refers to the statement in the Epilogue to 2 Henry IV that '(for any thing I know) Falstaff shall die of a sweat' and also to Dr. Caius' 'Counseill' against the Sweat.

${ }^{81}$ Quotidians and tertians have in fact nothing to do with the sweating-sickness, but Mrs. Quickly was not a clinician.

s8 2 nd ed. by Eversley \& others in 2 vols (1965): see vol. i. ch. v 'The Sweating Sickness', and vol. ii, p. 311 note.

ss Vol. 145, March 1889, pp. 324-36.

se See Dover Wilson's Henry V (1947) p. 141; see Sisson, New Readings in Shakespeare, ii, p. 59; Moyes, Medicine and Kindred Arts in Shakespeare (1896) pp. 25-27. 


\section{Why is the Doctor in 'The Merry Wives of Windsor' called Caius?}

Creighton argues that Falstaff's symptoms as described by members of his entourage -'shaked of a burning quotidian tertian' (per Mrs. Quickly)-lowness of spirits 'The King hath run bad humours on the knight' (per Nym)-and other evidence, correspond closely with Dr. Caius' description of the course of the disease. Creighton also refers to the facies Hippocratica: 'To figure the nose sharp as a pen against a green background is to produce, by one master-stroke, the dominant impression of the classical Hippocratic facies'. So he concludes that 'Dr. Caius' tract on the Sweat and its moral lessons had come under Shakespeare's notice, and that he had it in mind when he decided to make Falstaff die of "a sweat"; and he comes down against " $a$ ' babbled of green fields" and in favour of "his nose was, as sharp as a pen on a table of green fields"., 55

Although in announcing Falstaff's death Shakespeare does not specifically tell us that he died of 'a sweat', the manner of his death as described in Henry V, Act II, Scenes 1 and 3, is consistent with such a death, for he had at any rate an acute fever and died rapidly. His boy says to Pistol and Mrs. Pistol, the Hostess: 'Mine host Pistol, you must come to my master, and you, hostess: he is very sick, and would to bed.' Thereupon the 'Hostess follows the Boy' and (after 27 lines) she returns and urges Pistol and others to "come in quickly to Sir John ... he is so shaked of a burning quotidian tertian'. After a short Scene II, which concerned the King and his nobles, we learn from Pistol in Scene III that Falstaff is dead. He 'parted e'en just between twelve and one, e'en at the turning o' th' tide', and it is reasonable to suppose that this was the midnight which immediately followed the boy's summons of Pistol and the Hostess.

In the light of the impression made by the five dreadful visitations of 'the Sweat' between 1485 and 1551 upon the public memory and the popular chronicles, the remark in the Epilogue to 2 Henry IV that Falstaff shall 'die of a sweat' was good theatrical business. It referred to a specific disease which would be recognizable by most members of the audience. There are many illnesses which involve sweating but 'die of a sweat' could only refer to the terrible disease which had brought sudden and dramatic death to so many five times during the previous hundred and twenty years and might at any time recur, for it had disappeared as mysteriously as it came. Once Shakespeare had foreshadowed this fate for Falstaff and had decided that it was time for him to die, it would not be surprising if the name of Dr. Caius, the leading authority on 'the Sweat', should occur to his mind, although there is no mention of Dr. Caius in Henry $V$ and no suggestion that Falstaff received any medical attention on his death-bed.

In the 'Boke or Counseill' Dr. Caius gives two reasons why he writes in English instead of Latin or Greek: 'Necessite, for that this disease is almoste peculiar vnto vs Englishe men, and not common to all men, followyng vs, as the shadowe the body, in al countries, albeit not at al times ...'56

ss Blackwood's Magazine, vol. 145, at pp. 331, 334.

so P. 8. His second reason is 'good wyl to my countrie, frendes and acquaintance'. My references are to the Works of John Caius edited by Venn. See also, on Dr. Caius and the Sweat, Aikin, Medical Memoirs (1780), pp. 119-27.

In 1847 there was published a book written by Professor Gruner of the University of Strasbourg entitled Scriptores de sudore anglico superstites, in which he probably succeeded in bringing together almost every scrap that has been written concerning this fell disease, including of course both of 


\section{Lord McNair, Q.C.}

For ${ }^{57}$ touching the first reason, we see this sweting sickness or pestilence Ephemera, to be oft in England, but never entreth Scotland (except the borders), albeit thei both be joinctly within the compass of on[e] sea. The same beginning here, hath assailed Brabant [now a province of Belgium] and the costes nigh to it, but never passed Germany, where ones it was in like facion as here, with great mortalitie, in the yere MCDLIX. Cause whereof none other there is naturall, then [than] the evell diet of these thre countres ${ }^{58}$ whiche destroy more meates and drynckes withoute al ordre, convenient time, reason, or necessite, ${ }^{60}$ than either Scotlande, or all other countries under the sunne, to the great annoiance of their owne bodies and wittes, hinderance of theim which have nede, and great dearth and scarcitie in their common welthes.

The English tract of 1552 is definitely addressed to the layman. The author's object was to tell his fellow-countrymen the best way to avoid the disease and also, I think, to give them some 'first-aid' advice in the light of its deadly character and rapidity. In 1555 he published a much longer and more technical edition in Latin which was intended for the medical profession-De ephemera britannica. He tells us (in the English book) that this fearful disease began in 1485 shortly after Henry VII landed at Milford Haven in 'Wales: 'and because it firste beganne in Englande, it was named in other countries, "the englishe sweat".' He says (p. 10) that if he was free to give it a name he would call it 'Ephemera, which is to say, a fever of one natural dai', which was usually long enough to ensure death; at any rate if you survived for a day you usually recovered. He continues: 'A fever, for the fervor or burning, drieth and sweating fevre like.' He also says: 'This disease is not a Sweat onely . . . but a fever, as I said.' The subsequent dates of the visitations of this disease given by him are 1506, 1519, $1528^{\circ 0}$ and 1551. The last outbreak began 'at Shrewsbury $^{61}$ proceadinge with greate mortalitie to Ludlowe, Prestene, and other places in Wales, then to Westchestre, Coventre, ${ }^{62}$ Oxenforde, and other tounes in the Southe, and such as were in and aboute the way to London'-(causing many deaths) and 'thence throughe al the east partes of England into the Northe ...' By the end of September it had finished.

These visitations of the sweat or sweating sickness made a deep impression upon the public imagination, the medical profession and the contemporary chronicles. It was something hitherto unknown and it killed with dramatic suddenness. Dr. Caius speaks $^{63}$ of its 'soubdeine sharpenes and unwont cruelnes', and in the second edition

Dr. Caius's books. Among English authorities before 1600 he gives extracts from the works of Polydore Vergil (in Latin), Holinshed (1578), and Nicholas Sanders (in Latin, 1588). Gruner describes Dr. Caius as omnium qui de sudore anglico scripserunt princeps putandus est. Is it surprising that any dramatist writing in the last decade of the sixteenth century should regard a reference to this disease as a valuable topical allusion?

${ }^{67}$ P. 16.

ss England, Brabant and Germany.

50 Which defines a category into which Falstaff would fit well.

'0 In June 1528 Henry VIII at Greenwich was, of course, deeply alarmed by the news that 'a maid of Anne Boleyn's had been attacked by it.' 'He left in great haste for Waltham, and sent the young lady [to whom he was not yet married] to her father's in Kent' ... 'He sends his second physician Dr. Butts [of Gonville Hall, see D.N.B. and Venn, vol i] to her.' She was not ill at that moment but caught 'the Sweat' a few days later and recovered. (Creighton, op. cit., ii, p. 251.)

-1 It has sometimes been stated that Dr. Caius practised at Shrewsbury, but I do not think that this can properly be inferred from the fact that he was there when the 1551 occurrence of 'the Sweat' took place. He wrote of it 'Ipse, dum haec tragedia agebatur, praesens spectator interfui', which as Venn points out (College Biographical History, vol. III, p. 34) is 'more suggestive of a brief visit than of the position of a resident practitioner'. Dr. Caius was lucky to be there at such an interesting time and he made a scoop.

62 Stratford is 19 miles from Coventry and 64 from Shrewsbury.

as P. 9. 


\section{Why is the Doctor in 'The Merry Wives of Windsor' called Caius?}

of Holinshed's Chronicles (1587), ${ }^{\text {s4 }}$ we are told (vol. III, p. 763) (of the first visitation) that it was 'so sharpe and deadlie, that the like was never heard of to anie man's remembrance before that time'. Anyone who compares Holinshed (1587 ed., vol. III, p. 1066) with Dr. Caius' Boke or Counseill will not be surprised to find 'John Caius' in the margin of Holinshed's description of the reign of Edward VI; although Shakespeare wrote no play on Edward VI, it is obvious to anyone who peruses Boswell-Stone's Shakespeare's Holinshed that he was well read in Holinshed as in many other sixteenth-century chronicles. There are many references to the Sweat in general literature in the second half of the sixteenth century, including Nash's The Unfortunate Traveller, Grafton's Chronicle from 1189 to 1558, published in 1569 (pp. 160 and 412 in the 1809 edition); and John Stow in his Annales of England (1592, 1601 and 1605), another of Shakespeare's common sources of information, mentions 'John Caius' in the margin of page $1023^{65}$ when describing the Sweat of 1551 and says that it 'followed Englishmen as well within the Realme, as in strange countries'. Thus Holinshed in 1587 and Stow in 1592, 1601 and 1605 both recognize Dr. Caius as the leading authority on the Sweat, and Shakespeare echoes their language.

The following are some parallel passages from Dr. Caius' Counseill and Holinshed's Chronicles, ${ }^{\text {B6 }}$ second edition, 1587:

\section{Dr. Caius (p. 10)}

'some in one hour, many in two it destroyed, $\&$ at the longest, to them that merilye dined, it gave a sorrowful Supper." As it founde them so it toke them, some in sleape some in wake, some in mirthe some in care, some fasting and some ful .... if the haulfe in everye Towne escaped, it was thoughte great favour'.

\section{Dr. Caius (p. 17)}

After referring to the English habit of eating and drinking too much, he says that even Aesculapius could not save them 'except thei would learne a new lesson \& folowe a new trade. For other wise neither the avoidyng of this countrie (the second reason) nor fleying into others (a commune refuge in other diseases) wyll preserve us Englishe men, as in this laste sweate [that is, 1551] by experience well proved in Cales, Antwerpe, and other places of Brabant, when only our contrimen ware sicke, \& none others, except one or ii others of thenglishe diete, which is also to be noted.'
Holinshed, ed. of 1587, vol. III, p. 1066

.... It began in London on the ninth of Julie, and the twelfth of Julie it was most JoHn vehement: which was so terrible, that CAIUS people being in best helth, were suddenly taken, and dead in foure and twentie houres, and twelve, or lesse, for lacke of skill in guiding them in their sweat . . . But the waie to escape danger was close keeping moderatlie with some aire and a little drinke, and the same to be posset-ale, and so to keepe them thirtie houres, and then was the danger past; but beware of sudden cold. Before man had learned the manner of keeping, an infinit number perished. This disease at that time followed Englishmen and none other nation; for in Antwerpe and other countries, our Englishmen being there amongst diverse other nations, onely our Englishmen were sicke thereof, and none other persons.'

a The one which Shakespeare is believed to have used. I need hardly mention the fact that 'Holinshed' was one of Shakespeare's bedside books - see Boswell-Stone, Shakespeare's Holinshed (1896), and Churton Collins, Studies in Shakespeare (1904) ch. VI ('Shakespeare and Holinshed'). Holinshed in his Will described himself as of Bromecote (Bramcott) in Warwickshire, not far from Polesworth.

os In the 1592 ed.; and p. 1021 in the 1601 and 1605 eds.

co Dr. Caius' dates and Holinshed's dates of the visitations do not completely correspond, but that is immaterial for our purpose.

"7 Creighton, op. cit., i. p. 262 cites a contemporary statement 'there were some dancing in the Court at nine o'clock that were dead at eleven'. 


\section{Dr. Caius (pp. 29, 30)}

'Serve nature we shall, if in what time so ever it shall take us ... we streyghte lay us downe uppon oure bedde, yf we be up and in oure clothes, not takying them of: or lie stille, if we be in bed out of our clothes, laiyng on clothes both wayes, if we wante, reasonably and not loadinge us therewith unmeasurably . . . Oure kepers, friends and lovers must also endevoure theym selves to be handesome and dilygente about us, to serve us redilye at al turnes, and never to leave us duringe foure and twentie houres, but to loke welle unto us, that neyther we caste of oure clothes, nor thruste oute hande or foote, during the space of the saide foure and twentye houres.'
Holinshed, ed. of 1587, vol. III, p.764

-... a remedie was founde for that mortall maladie, which was this. If a man on the day time were taken with the sweat, then should he streight lie downe with all his clothes and garments, and continue in his sweat four and twentie houres, after so moderate a fast as might be.

If in the night he chanced to be taken, then should he not rise out of his bed for the space of foure and twentie houres, so casting the clothes that he might in no wise provoke the sweat ... Marie [Marry] one point diligentlie above all other in this cure is to be observed, that he never did put his hand or feet out of the bed to refresh or coole himselfe, which to do is no lesse jeopardie than short and present death.'

Holinshed, ed. of 1587, vol. III, p. 844

'This maladie was so cruel, that it killed some within three houres, some within two houres, some merrie at dinner and dead at supper.'

I shall place in parallel columns (on p. 327) the descriptions given by

(a) Hippocrates, in the Loeb translation (not of course available to Shakespeare);

(b) Peter Lowe, a Scottish doctor who published in London in 1597 an English translation of the Hippocratis Prognosticon, apparently from a French book;

(c) Mrs. Pistol, whose vivid picture makes it clear that Shakespeare either knew or took the trouble to find out the distinctive symptoms and signs of approaching death in the case of acute fevers when he entrusted her with the task of describing them. Once he had decided to kill the old man by means of 'the Sweat' it is just like him to make some enquiry and to do the job properly.

In some of Shakespeare's plays in which the doctor has merely a walking-on part no name is necessary. But the doctor in The Merry Wives was important enough to have a name. Why Dr. Caius?

For some students of the play it may suffice that it was a royal command and that at any rate one member of the audience-the Queen-might remember that when

${ }^{68}$ The Loeb text vol. ii, p. 15 translates 'arms', but the Greek word can mean both 'arms' and 'hands', and the latter is clearly preferable here.

's supervacue venetur.

70 The following is one of the many Latin translations of this paragraph:

Praesagia de gesticulatione manuum (Mrs. Pistol's fumble) In acutis febribus, si quis eas [manus] faciei admoverit, ut inde quodpiam supervacue venetur, aut festucas carpat, aut a veste floccas avellat omnes hae [notae] malae letalesque sunt. Carphology is defined in the O.E.D. as 'the movements of delirious patients, as if searching for or grasping at imaginary objects, or picking the bed-clothes; floccilation.' See above, p. 326 (Dr. Caius and Holinshed) on the danger to the patient of casting off clothes.

"I I shall not embark upon this controversy. Dover Wilson prefers 'a babbled o" green fields'. His note on 'as sharp as a pen' is: 'i.e. as a goose-quill (dead white) lying point downwards, the "nib" or "neb" (=beak) being the nostrils', and he quotes Lupton, Thousand Notable Things (1578) bk. ix: 'If the foreheade of the sicke waxe redde-and his nose waxe sharpe-if he pull strawes, or the cloathes of his bedde-these are most certaine tokens of death' [notae malae letalesque]. 
Why is the Doctor in 'The Merry Wives of Windsor' called Caius?

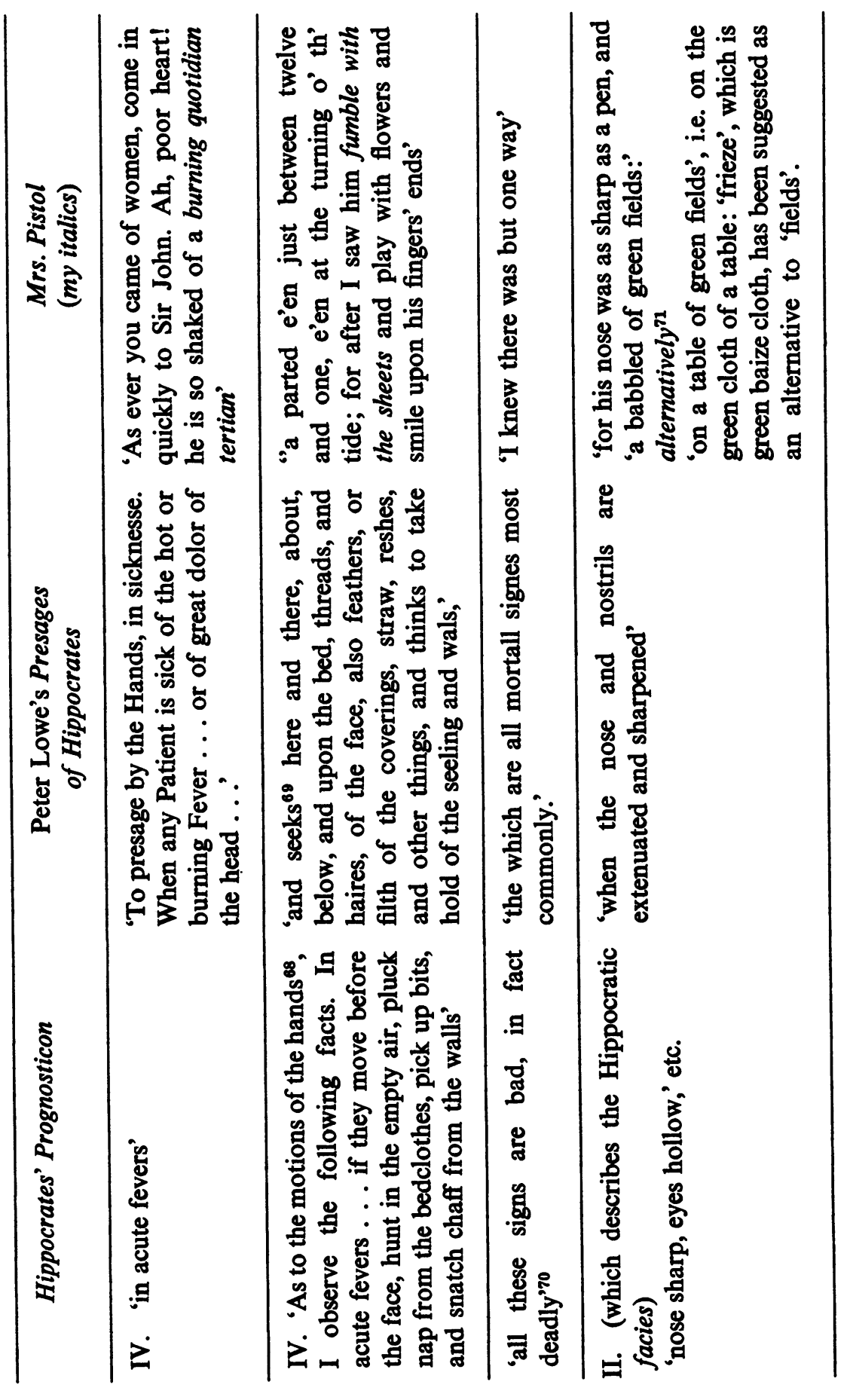




\section{Lord McNair, Q.C.}

she came to the throne in 1564 she had inherited from Mary a physician called John Caius whom in 1568 she felt it necessary to dismiss on the ground that he was a Catholic (having originally-according to the D.N.B.-been a Protestant) and who died in 1573. When the Queen made a royal progress to Cambridge in 1564 he took part in a medical disputation before her, ${ }^{72}$ and her maids of honour were lodged in Gonville and Caius College. If this is the explanation one would have expected that Shakespeare would have taken the trouble to make some enquiries regarding $\mathrm{Dr}$. Caius, for anything more unlike the Dr. Caius of the play could hardly be imagined. He was a grave scholar and the most distinguished physician of the century, and nothing is recorded concerning him which could induce an author to think that he was promising material for a buffoon. Like other physicians of the same calibre he had spent some years abroad, but he was pure English and there is no reason to believe that he had any peculiarities of speech. This being so, we feel bound to explore the question whether there are any other circumstances which can explain Shakespeare's adoption of the name.

There are at least four possible explanations of the way in which Shakespeare became aware of Dr. Caius and decided to give that name to the French doctor in The Merry Wives:

1. That he could have acquired or enlarged his knowledge of Dr. Caius and of medicine by conversation with Dr. John Hall of Stratford, who married Susanna Shakespeare in 1607;

2. That the original name of the doctor in The Merry Wives was Lopez and that circumstances made it necessary to substitute the name of Caius;

3. That he knowingly adopted the name of our Dr. Caius and made use of his reputation for irritability and dislike of the Welsh;

4. That he merely wanted a name bearing medical associations.

1.

SHAKESPEARE'S ASSOCIATION WITH DR. JOHN HALL OF STRATFORD ${ }^{73}$

It has been suggested not only that Dr. John Hall, who married Shakespeare's daughter Susanna on 5 June 1607, may have been a source of Shakespeare's medical allusions but even that he may have reported to Shakespeare some old Cambridge stories about Dr. Caius which had survived his death in 1573. John Hall is an interesting person in his own right, and played an important part in local affairs.

\footnotetext{
72 He was either somewhat nervous or feeble, because she found it necessary to say to him and the other disputant: Loquimini altius (Nichols, Progress of Queen Elizabeth, i, 171).

${ }^{73}$ Raach, Directory of English Country Physicians, 1603-1945 (1962).

See the following, in addition to the D.N.B. by Sidney Lee:

Stopes, Shakespeare's Warwickshire Contemporaries (1896).

Bucknill, J. C., Medical Knowledge of Shakespeare (1860), pp. 1-51 and 66-68;

Fripp, Shakespeare, Man and Artist, 1938 and 1964.

Arthur Gray (Master of Jesus College, Cambridge), Shakespeare's Son-in-law (1949);

Mitchell, The Shakespeare Circle-a Life of Dr. John Hall (1947);

Simpson, Shakespeare and Medicine (1959) ch. vi, 'Influence of his Son-in-law, Mr. John Hall Physician.'

Genealogists Magazine, 1936, p. 344; 1937, p. 478.

Marcham, Shakespeare and His Daughter Susanna. (Grafton, 1931).

There is also an article on Dr. Hall in a New York journal, the Medical Record, by Walter Lindley, which I have not seen.
} 


\section{Why is the Doctor in 'The Merry Wives of Windsor' called Caius?}

He is just about as close to Shakespeare's personal and family life as we can get today, and much has been written upon him. Our present interest in him centres on the date at which Shakespeare and his future son-in-law first became acquainted because, if we find in a play evidence of an unusual degree of familiarity with, or access to, medical knowledge on the part of Shakespeare, we are bound, or at least entitled, to enquire at what date and from what source that knowledge became available; the answer to this question could also have some bearing on the date of a play.

So it is that it is desirable to know whether John Hall had any opportunity of studying medicine in Cambridge, either as an undergraduate or as a Bachelor of Arts or as a Master of Arts, and what he did after leaving Cambridge in 1597. But before we examine the claims of the supporters of Dr. John Hall as the source of Shakespeare's medical knowledge, we must recall the state of the popular knowledge of health and medicine at that time. Dr. Poynter's contribution to the Shakespeare Survey 17, entitled 'Medicine and Public Health', is most illuminating on this matter. A man and his wife of Shakespeare's time and place in society probably knew as much about medical care in the home, medical self-help, as the corresponding couple of today, or more. At that time a limited amount of medical knowledge was still a part of general knowledge, and every married woman would know something about simples and would have her little book of recipes, which she had probably copied from her mother's book when she married. ${ }^{74}$ We must not assume that whenever Shakespeare or one of his contemporaries found it necessary to deal with medical matters, he had to consult a medical practitioner. Nevertheless if a playwright's daughter chanced to marry a doctor it is entirely reasonable to expect that from time to time he would pick his son-in-law's brains when they were available to him, if he wished to supplement or confirm his own knowledge.

We shall try to distinguish between the known facts concerning Dr. John Hall and the inferences and conjectures which abound.

FACTs: Venn's Alumni Cantabrigienses, Part I to 1751, vol. ii, tells us that a 'John Hall matriculated pensioner [that is, in popular language, as a normal undergraduate] from Queens' College, Michaelmas 1589. Of Bedfordshire. ${ }^{75}$ B.A., 1593-4; M.A., 1597 as Hale.' Thereafter there is no known connection between him and the college or the university. He took no medical degree in Cambridge. He appears next on the page of history in 1607, when he married Susanna Shakespeare, but the interval is, so far as facts are concerned, a blank.

INFERENCES AND CONJECTURES: THE MONTPELLIER MYTH

There is no evidence as to what he did between the dates of his B.A. (1593-4) and his M.A. (1597) degrees, and there is no doubt that the M.A. degree then involved three years further residence in Cambridge. I think that we are justified in coming to the conclusion that, while he could have listened to formal lectures read by the Regius Professor of Medicine after taking his M.A. degree, he obtained no real medical training in Cambridge; for it is very unlikely that at that time members of Queens'

${ }^{74}$ For the medical knowledge and practice of women in the sixteenth century and earlier, see Manton, Elizabeth Garrett Anderson, ch. iv.

${ }^{75}$ Gray, op. cit., p. 3, states that 'In college admission books the county stated is invariably that of birth'. 
could obtain such medical training, including dissection, as William Harvey was getting in Caius. So what did he do? There is a widespread desire among modern commentators to send him to a French university, and in particular to Montpellier. Gray $^{76}$ tells us that after taking his M.A. degree "he studied medicine, apparently at a French university, and could scarcely be engaged in professional work much before 1600 ', and 'Neither in the case book nor from any Stratford sources do we get any clue as to the date when Hall began his residence at Stratford'. ${ }^{77}$

Simpson, referring to Gray as his authority, says ${ }^{78}$ 'There is evidence that after 1597 John Hall studied abroad in France, almost certainly at Montpellier, where Rabelais had been the great medical professor.' The following passage occurs in volume 7 of the Genealogists Magazine (1935-1937): John Hall 'must have been studying medicine, first of all at Cambridge, later probably at some French university -Montpellier was the favourite one of the period for Protestant Englishmen.'

\section{WHAT OPPORTUNITIES OF MEDICAL TRAINING WERE AVAILABLE TO JOHN HALL?}

It is clear that some amount of medical education could be obtained then at any rate in one Cambridge college-Gonville and Caius. Sir Geoffrey Keynes ${ }^{79}$ tells us in his Life of William Harvey (p. 9) that Dr. Caius (who died in 1573) was regarded as the founder of the study of anatomy in England and that he obtained a "charter from the Queen enabling the Master and Fellows of his college to have each year for dissection the bodies of two criminals executed in Cambridge or in its Castle' (p. 10). Their remains were subsequently interred in a reverent manner in the presence of the Master and Fellows. Again he tells us (p. 12) that in 1571 Archbishop Parker 'founded a medical scholarship at Caius College.' There can be no doubt that when William Harvey was an undergraduate (1593 to 1596-7) his College did provide definite instruction in medical studies, as appears from the following extract from the same Life of William Harvey (p. 14):

Sir Charles Scarburgh, ${ }^{80}$ a close friend of Harvey's later years, said in his Harveian Oration at the College of Physicians in 1662 that at Cambridge "he drank in philosophy and medicine, and from the purest and richest spring of all, if there be such another dedicated to Apollo in the British Isles.' [Footnote. Bodleian Library, MS, Rawl. D. 815. First identified by L. M. Payne, J. Hist. Med., 1957, 12, 158-64. Here quoted from a translation by W. R. Le Fanu.] Scarburgh strengthened this claim by relating how he was once called to a consultation over a very ill patient in company with six other physicians, Harvey being the chief. It was found that every one of the seven had been an undergraduate at Caius College. Clearly, therefore, opportunities for a medical education were exceptionally good there, and since Harvey, as we shall see, spent little more than two years at Padua before graduating as M.D., he must have had a good grounding in medicine at Cambridge-though in another passage Scarburgh asserted that Harvey's final decision to excel in medicine was not made until he went to Padua.

In another passage in the same book (pp. 20, 21) we are told that 'A Statute of 1558 at Harvey's college, recognizing that the medical instruction available at Cambridge was not adequate for full training as a doctor, allowed Bachelors of Arts wishing to

76 Gray, op. cit., p. 10.

"It p. 15. At p. 17 Gray says 'at a Protestant French University'.

78 P. 93 .

79 To whom I am much indebted for leave to make several quotations.

so Gonville and Caius College Biographical History, i, p. 308; he was admitted to the college as a sizar in 1632 . 


\section{Why is the Doctor in 'The Merry Wives of Windsor' called Caius?}

pursue a medical career to leave the University and to go to Padua, Bologna, Montpellier, or Paris. Harvey, following the footsteps of both Linacre and Caius, chose to go to Padua, then at the zenith of its fame as a school of medicine.' Presumably Bachelors of Arts who went abroad in order to complete their training did not get their M.A. degree unless they returned to Cambridge and resided for three more years. They were probably content with their foreign degrees or they incorporated at an English or Scottish university by taking the equivalent degree.

Sir Humphry Rolleston, in his Cambridge Medical School (1932), writes regarding the sixteenth century: 'Medical students who wished to get real teaching were obliged to seek it elsewhere, as Harvey, Caius and others did at Padua, and none of them when they came back to England founded a school at Cambridge' (p. 8). 'Medical teaching, such as it was, from the birth of the University until the nineteenth century, consisted in the reading and expounding of Hippocrates, Galen and Aretaeus, and was devoid of the experimental method in which Harvey could have led the way' (p. 9). These statements relate to the University and are not fully applicable to Gonville and Caius and possibly one or two other colleges, but so far I have found no evidence of medical teaching by any other College.

The matricule of the university of Montpellier ${ }^{81}$ covering the period 1509 to 1599 is in the Cambridge University Library and contains no mention of John Hall; and the Dean of the Faculty of Medicine of Montpellier assures me that he can find no trace of John Hall at any time. Nor does his name appear in the records of the University of Leyden, also well known for medicine. ${ }^{82}$

In an appendix (p. 339) there will be found a note written by Professor Pierre Timbal, who at the request of my friend Professor René David of the University of Paris has investigated the possible connection of John Hall with that University. There is every reason to suppose that he was a Protestant, for he was married in the parish church and closely associated with it as churchwarden, sidesman and vicar's warden. ${ }^{82 a}$ The Edict of Nantes of 1598 enabled Protestants to enter the universities and colleges, which did not, however, necessarily mean that they could obtain degrees. It is probably impossible to assert that John Hall did or did not attend lectures at any French university, because university records are primarily concerned with graduates. Nevertheless, as the appendix indicates, it is possible that a prolonged investigation might reveal the names of English students attending lectures in the University of Paris, though the University of Montpellier, by reason of its Protestant associations,

11 Of course, the University of Montpellier was famous. But the desire of modern commentators to send John Hall there amounts almost to a conspiracy. Can it be that this is due to the fact that the word 'Montpellier' occurs in a tract of 6 pages by Dr. W. Stubbs entitled Ars Cosmetica, which is bound up with John Hall's 'Select Observations on English Bodies', as translated by James Cook, at any rate in the edition (1679) available to me? On p. 349 we find a recipe 'To make the Verjuyce of Montpelier, [sic] which is highly esteemed in France for the Complexion'. The Dictionnaire pharmaceutique ou Apparat de Medecine Pharmacie et Chymie, 2nd ed. (1589), under the title of 'Eaux minerales artificielles' states: 'Pour préparer la seconde eau minérale artificielle chalybée, on prendra deux onces de Tartre de Montpellier pulverisé, et une dragme de limaille d'acier, ou de fer tout pur et non preparé. Cet eau est fort aperitive...'This is the only mention of Montpellier that I can find in the Select Observations. Is it possible that someone interested in John Hall while perusing this book spotted the word 'Montpelier' [sic] and came to a too hasty conclusion?

${ }_{82}$ Album Studiosorum, 1575-1875. Peacock, Index to English-speaking Students who have graduated at Leyden University (1883); Smith, R. W. S., English-speaking Students of Medicine at the University of Leyden (1932.)

sia Lee, Life of William Shakespeare (ed. of 1915) p. 463, 508. 
might have been more attractive to John Hall. I am not prepared to instigate any further investigation.

In the D.N.B. life, published in 1890 , since when more has become known, Sidney Lee stated that John Hall was "well educated, [had] travelled abroad, and acquired a good knowledge of French. He called himself master of arts but his university is not known, and, although he practised medicine, he had no medical degree.' No date of his arrival in Stratford is given. He was the son of William Hall of Acton, Middlesex, whose will is given in Gray's book already mentioned. From this document it appears that the testator had certain 'bookes of phisicke' which he bequeathed to his son John and certain 'bookes' of 'Astronomie', 'Astrologie' and 'Alchimye' which he bequeathed to his servant. From the contents of his will it has been assumed that William Hall was a physician of an old-fashioned type, addicted to astronomy, astrology and alchemy, but there is no evidence of any qualification or of a licence, which at Acton within seven miles of the City of London would be necessary. ${ }^{83}$ Raach referred to in footnote 73 above lists a William Hall at Carlton ${ }^{84}$ in Bedfordshire 'c. 1600' and at 'Acton ?1607', doubtless the father of John.

We learn from the books referred to in footnote 73 that during our Civil War James Cooke (or Cook), a medical doctor, serving in the Parliamentary army, visited Mrs. Susanna Hall in Stratford and learned in the course of conversation that among her deceased husband's books and papers was a small duodecimo volume entitled Select Observations on English Bodies of Eminent Persons in desperate Diseases, ${ }^{85}$ in which he had kept notes of all or many of his patients from the year 1617 onwards. Having acquired the volume from her, either as a gift or by purchase, James Cooke then 'englished' it and published it in 1657, which seems to be a most unethical proceeding that he sought to justify in a preface. The volume contains detailed notes of the ailments of named and recognizable patients, both members of the aristocracy and humble neighbours, and the results of the remedies prescribed by him, the drastic character of some of which make one shudder; and the preface to the edition of 1657 (the first) states that John Hall 'had been a Traveller acquainted with the French tongue, as appeared by some part of some Observations, which I got help to make English.'

If, as appears to be the case, John Hall could not usefully remain in Cambridge, after 1597 and went neither to Montpellier nor to Paris nor to Leyden, is it not likely that he did the natural and dutiful thing, namely, lived for some time with his medicoastrological father at Carlton in Bedfordshire and/or Acton in Middlesex and in this way learned his profession? Certain passages of William Hall's willse are interesting. It is dated 12 December 1607, and the testator died on 19 December. John Hall was

as In London and its Environs Described, published by R. and J. Dodsley (1761), we find in vol. 1, p. 132 'Acton (East) a village six miles from London' and 'Acton (West) a village in the road to Oxford, situated seven miles from London'.

\& It is stated in the Victoria County History, Bedfordshire, vol. III, that Queens' College acquired in 1568 property in Oakley and Clapham near Bedford. Carlton where William Hall lived is about three miles from Oakley. These facts may explain why John Hall went to Queens' College.

${ }^{85}$ Now in the British Museum, Egerton Manuscripts No. 2065. The 1679 edition of this book is in the Cambridge University Library. There are three editions in the British Museum and the manuscript is also there.

${ }_{86}$ Printed by Gray, op. cit., pp. 4-6, who has obtained a good deal of information regarding William Hall. 
appointed executor, but the will contained the following provision: 'Provided further that yf my sayed sonne John do refuse to be executor and to paye the legaceys abovewritten That then my son Dive should take uppon hym the foresayed execution of my testament; my will ys paying unto my sayed sonne John fiftie pounds together with all my bookes of phisicke ...' John declined to take up the executorship in regard it would be a hindrance in his profession of being a physician'; as we know, he then was at Stratford having married Susanna some six months earlier. I am aware of no evidence as to the date at which he began practice in Stratford or the reason why he settled there. In my opinion the important question is not whether it was possible for John Hall to be capable of giving medical information to Shakespeare, but whether it was possible for this to happen before The Merry Wives was written.

I have therefore certain doubts about identifying John Hall as the main source of any medical information that Shakespeare may have required.

2.

The second possible explanation is Dover Wilson's interesting conjecture that Dr. Caius of the play was originally Dr. Lopez or Lopus. In Shakespeare's Happy Comedies, ${ }^{87}$ after referring to a note of mine on Dr. Caius, ${ }^{88}$ he continues as follows: 'To which I venture to add the conjecture that the name was originally Lopez, that of the Portuguese Jew who spoke, and wrote, broken English, who was the Queen's physician, but whose death on the gallows in 1594 would make his name inappropriate in a comedy.'

Dr. Lopez was one of the most fashionable foreign physicians practising in London towards the end of the sixteenth century. He was a Portuguese Jew, described in the census of 1571 as 'Doctor Lopus, a portingale, householder denizen' who 'came into this realm about twelve years past to get his living by physic'. ${ }^{89} \mathrm{He}$ was the first person to hold the office of house physician at St. Bartholomew's Hospital, became a member of the College of Physicians before 1569 and chief physician to Elizabeth in 1586, eighteen years after she had dismissed Dr. Caius (another 'Bart's man'). Lopez stood high in her favour and she had granted him two monopolies. Suddenly in January 1594 he was arrested on the ground of complicity in a plot to kill Elizabeth by poison and, after a very unsatisfactory trial by an ad hoc commission presided over by Essex, was found guilty and hung in June 1594 after Elizabeth had delayed in signing his death-warrant for three months. ${ }^{90}$ It is not surprising that the trial and conviction of Dr. Lopez was responsible for a wave of very strong feeling against members of his race.

\footnotetext{
${ }^{87}$ P. 83, n. 1; see also pp. 112, 113.

${ }^{88}$ The note occurred in The Caian, vol. XXVIII (1920) and is as follows: 'We are entitled to infer that John Caius was well enough known twenty-five years after his death for his name to suggest to a London audience a distinguished physician, but not so well known that the appearance of his name-sake in the guise of a Frenchman would be regarded as an unpardonable incrongruity'.

${ }^{80}$ See sources listed in D.N.B., and Wolf, 'Jews in Elizabethan England', Transactions of Jewish Historical Society of England, 1924-1927, 11; Ward, Doctor Faustus, p. 197, citing Sidney Lee in The Gentleman's Magazine, February 1880 on 'The Original of Shylock', Dimock on 'The Conspiracy of Dr. Lopez' in English Historical Review, July 1894, and Frank Marcham, 'Lopez the Jew' (1927). According to Dover Wilson, Merchant of Venice, Cambridge text, p. 117, 'Lopez was popularly known as Dr. Lopus.'

See Lytton Strachey, Elizabeth and Essex, ch. VI-a terrible story.
} 


\section{Lord McNair Q.C.}

Contemporary playwrights, ever sensitive to what was passing through the minds of their public, were naturally affected by this sensation, and their reaction to it is reflected in references in several plays to Jews. Dover Wilson ${ }^{91}$ refers to the trial and execution of Lopez as a factor influencing the re-creation or a 'second handling' of the Merchant of Venice out of an older play, and the unfairness of the trial of Lopez may have been a factor contributing to Shakespeare's more humane and better balanced attitude to the Jews than that which was current at that time. In 1607 there occurs in Dekker's The Whore of Babylon a character called Dr. Ropus, who, according to Fredson Bowers, editor of the 1955 edition, was earlier called Lupus. ${ }^{92}$ Middleton's $A$ Game at Chesse, ${ }^{93}$ first played in 1624 , contained a Taxa poenitaria-a 'Booke of generalle pardons of all prices'; it appears from the following passage that a reference to Doctor Lopez was still good theatrical business: 'Black Knight. Promised also to Doctor Lopez for poysonning the Mayden Queene of the white kingdome ducketts 20 thousand, which sayde Summe was afterwards giuen as a meritorious Almes to the Nunnerie at Lisbon ....'

In a court play performed before the Queen in 1592 or 1593 which ridiculed a foreign physician to the Queen it would not be surprising to find that the original of the character was Dr. Roderigo Lopez, a Portuguese Jew. There is no doubt that he was a very good physician but he does not appear to have been an attractive character and he was probably the target of a good deal of envy. The D.N.B. quotes Gabriel Harvey as describing him as 'none of the learnedest or expertest physitians in the court, but one that maketh a great account of himself as the best, and by a kind of Jewish practis has growen to much wealth and sum reputation as well with ye queen herself as with sum of ye greatest Lordes and Ladyes.'

This is just the kind of man whom a court audience might like to see 'guyed' and, provided the joke was not carried too far, it might even amuse his royal patient, who valued him highly. Though not a French doctor, it is highly probable that a man of his upbringing and professional distinction could speak French. It is, however, clear that after his arrest and trial in 1594 it would be impossible to perform a comedy containing anything that would remind the audience of the Lopez affair and the mortal danger to which the Queen was thought to have been exposed. If, however, a court physician was regarded as an essential character in a play, it might be possible to substitute for Lopez the name of one of his predecessors, Caius, who had held the same post until dismissed by the Queen in 1568.

3.

The third possible explanation is that Shakespeare, rather than call the medical man merely 'Doctor' as he did in several plays, ${ }^{94}$ adopted the name of the real Dr.

"1 See Cambridge edition of The Merchant of Venice, pp. 116-19.

In Scene V of Act IV of Marlowe's Dr. Faustus written and performed before the trial of Dr. Lopez, there occurs the following passage: Faustus 'Away you villain! what dost think I am a horse doctor? . . Re-enter Horse-courser. Horse-c. 'Alas, alas! Doctor Fustian, quotha? mass, Doctor Lopus was never such a doctor: has given me a purgation, has purged me of forty dollars ...'

a P. 494. What appears to be line 129 on p.538 is as follows:

't Lopes [in the margin] Campeius and † Ropus'.

- Cited by Dyce, Ward and others; amongst other editions may be mentioned that by Bald in 1929 (Cambridge University Press), pp. 102 and 155.

ou See Simpson, op. cit., chapter 5. 


\section{Why is the Doctor in 'The Merry Wives of Windsor' called Caius?}

Caius although he had ceased to be a court physician in 1568 and had been dead for at least twenty-five years, without attempting to describe or identify the owner of the name. Shakespeare must have known the name of Dr. Caius as the leading English physician of the century and did not need Dr. John Hall or anyone else to tell him. Moreover, as I have tried to shew, he was probably aware of Dr. Caius' important Boke or Counseill against 'the Sweat', which, thanks to Holinshed and Mrs. Quickly, helped him to give Falstaff a good death. It is true that The Merry Wives is not a historical play and that Shakespeare was under no obligation to name or depict an actual doctor, unlike the case of Henry VIII (in so far as it can be attributed to him) where a well-known royal physician has a very small part in the play and yet bears his own name-William Butts, ${ }^{95}$ the friend and fellow-collegian of Dr. Caius. This is unusual. So dependent was England on foreign doctors at this time that, as has been shewn above, the regular practice of the stage was to give a doctor a foreign name or at any rate an 'outlandish' name, if he was of enough importance to have a name at all.

But, it has been said, there are two other characteristics of the real Dr. Caius which indicate that Shakespeare had him in mind, firstly, Dr. Caius' dislike of the Welsh ${ }^{96}$ and, secondly, his quarrelsome nature. As to the former, the only evidence known to me is that in one of the Statutes given to the college by Dr. Caius, and entitled Qui non eligendi, which appears to apply to the election of the Master and Fellows and Scholars, there occurs the following passage: 'Nullum praeterea deformem, mutum, caecum, claudum, mancum, mutilum, Wallicum, aliquo gravi aut contagioso morbo affectum, aut valetudinarium, hoc est, magna ex parte aegrotum, eligendum vobis esse: et si eligatur, excludendum constituimus.'

Arthur Gray"7 conjectures that 'In John Hall's student days stories lingered in Cambridge of the violent quarrels with the University officials-particularly of his vehement dislike of Sir Hugh Evans' countrymen whom he expressly excluded from his foundation.' The Statutes comprising the anti-Welsh Statute were made in 1572 and Dr. Caius died in 1573. I find it difficult to believe that Shakespeare would regard this incident as of sufficient importance and relevance to justify him in putting Dr. Caius into a comic play as the antagonist of a Welshman.

Dr. Caius, born in Norwich, came of a Yorkshire family. His college recruited its members predominantly from the eastern counties and many of its manors and livings were connected with those counties. Among the members of the college until the time of Dr. Caius I can only find one Welshman-John Stradlyng, fellowcommoner 1560, and I can find no reason why Dr. Caius and he should clash. I believe that when the Tudors came to the throne they were naturally followed by a number of the Welsh, some of them doubtless in search of jobs, which caused some general unpopularity. ${ }^{98}$ The same thing, I believe, happened to the Scots who came south with King James $I$.

"3onville and Caius College Biographical History, i, p. 17.

- Harries, Shakespeare and the Welsh (1919); Cumberland Clark, Shakespeare and National Character (1934). Professor Bradbrook points out that Dr. Caius and Sir Hugh Evans are antagonists, thirsting for a duel.

7 Op. cit., at p. 17.

"2 He may have met some Welshmen in Shrewsbury in the course of his professional visits to that town. 
As for the charge of a quarrelsome nature, Dr. Caius lived in a quarrelsome century. Although, according to the D.N.B., he was at one time a Protestant, ${ }^{99}$ he became a very devout Catholic and was frequently involved in religious disputes and the personal disputes engendered by them. His college became what he might have described as 'a hot-bed of Puritanism'. Dr. Venn ${ }^{100}$ wrote as follows:

\begin{abstract}
As we have said, Dr. Caius became master Jan. 24, 1558-9. Splendid as were his services to education, and keenly as he interested himself, in every direction, in the past history and future fortunes of his college, his domestic rule there was far from successful. Several causes contributed to this result. The master, though not old, as we should now reckon, was prematurely aged, of somewhat feeble health, and apparently of gloomy and irritable constitution. He was a great admirer of the past, with little sympathy for new views, whether religious, political or educational. In fact there is no reason to believe that he ever ceased to be at heart a decided Roman Catholic. The fellows, mostly if not entirely, were of the new way of thinking, Puritans; and apparently narrow-minded and bitter in spirit. Not one of them achieved any distinction in after life. They were also very young:-it is often overlooked how very youthful the resident body in college generally was in those days. As far as I can ascertain, not one of the fellows of the college was over 24, in the year 1564, when the quarrel was at its height; and their average age was but 22. One must be older (or younger) than this to believe that those in authority can be in the right. Even therefore if the college had stood alone, it would have been difficult enough to preserve the peace, but the contagion and suspicion of hostility had spread through the University and the country, and those who took either side of the controversy were sure to find many to urge them further on. For instance, in a letter to the Chancellor, a few years later, Dr. Caius is mentioned along with several other of the masters, and it is added 'they are all either enemies unto God's Gospel, or so faint professors that they do little good in the Church.' We shall see presently to what lengths the bigotry and fanaticism of the fellows could lead them directly they secured the support of the Vice-Chancellor in their attack upon their Master.
\end{abstract}

It is not surprising that Archbishop Parker should write, in a letter to the Chancellor dated in or about 1566, 'I have had very moche adoo with the quarrels of Gonvel Hall from tyme to tyme. The truth is both parties ar not excusable from folye'.

That echoes of these truths should be in circulation in London thirty years later, and twenty-five years after the death of Dr. Caius, is unlikely. In any case they do not seem to throw much light upon the peppery French doctor of The Merry Wives. ${ }^{101}$

4

The fourth and last possible explanation is that Shakespeare merely wanted a medical name and was not interested in the question of any other association with that name. If it be true that The Merry Wives was knocked together hurriedly for a special occasion and without much expectation that it would become a part of the company's permanent repertory, one could understand why he should give the conventional stage doctor a name which incidentally the Queen might recognize as that of her former physician. The mere borrowing of the name could occur without any intention of lampooning the doctor. In other words, he may have used the name

๑O But see Venn, i, p. XIV.

100 Gonville and Caius College Biographical History (1901), iii, p. 43.

101 In $A$ Book about Doctors, by J. C. Jeaffreson (1861) there occurs on p. 11 the following extraordinary statement, for which (so far as concerns The Merry Wives) I can suggest no explanation: 'As a president of the College of Physicians Caius was a zealous defender of the rights of his order. It has been suggested that Shakespeare's Dr. Caius, in The Merry Wives of Windsor, was produced in resentment towards the president, for his excessive fervour against the surgeons.' It is true that feeling between the physicians and the surgeons ran high, but I can see no reason why Shakespeare should be regarded as a champion of the latter body. 


\section{Why is the Doctor in 'The Merry Wives of Windsor' called Caius?}

without attempting to portray the character of its owner, just as Galeno occurs in an Italian scenario, ${ }^{102}$ and simply as a convenient means of indicating to the audience that this character is a doctor. Many such instances occur in literature, dramatic and otherwise.

I hope that I have now shown how natural it was for Shakespeare to put a comic French doctor with an outlandish name into this play. But why should the name be Caius? There is no reason to suppose that there was ever any contact, much less conflict, between Shakespeare and our Dr. Caius. Shakespeare was born in 1564 and Dr. Caius died in 1573, leaving no issue. I can see no reason why Shakespeare should wish to hold Dr. Caius up to ridicule, nor can I find any evidence of any other playwright representing Dr. Caius as a figure of fun and putting such an idea into Shakespeare's head. In short, I submit with confidence that the Dr. Caius of the play was not intended by Shakespeare to be a picture of Dr. Caius, the Master of Gonville and Caius College. Dr. Caius of the play was a name-a familiar medical nameand no more. Nor do I attach any importance to the fact that Page calls him 'the renowned French physician'. It increased the fun to see a distinguished physician being fooled and making a fool of himself. Moreover, a physician is often said to be 'distinguished', just as counsel are usually described by journalists as 'eminent'. These general grounds would, I suggest, alone be enough to explain why Shakespeare used the name in the circumstances of this play. It would help an author if at any rate a portion of his audience at once realized that a character called 'Caius' must be a doctor, just as the use of the name 'Osler' or 'Horder' would have done a generation ago. A well-known name is a shorthand means of telling the audience at once what this character's profession is.

I must mention some solutions of the problem that have been suggested. An early, perhaps the earliest, comment upon the possible similarity of Shakespeare's Dr. Caius to Dr. Caius of Cambridge occurs in the Essay on the Learning of Shakespeare (1767) by Dr. Richard Farmer (1735-1797), master of Emmanuel College, as follows:

It has been thought strange that our author should take the name of Caius [an eminent physician who flourished in the reign of Elizabeth, and founder of Caius College in our university] for his Frenchman in this comedy; but Shakespeare was little acquainted with literary history; and without doubt, from this unusual name, supposed him to have been a foreign quack. Add to this, that the doctor was handed down as a kind of Rosicrucian: Mr. Ames had in MS. one of the Secret Writings of Dr. Caius. ${ }^{103}$

Dover Wilson has suggested ${ }^{104}$ that much of the raw material that went into The Merry Wives may have come from a lost play, The Jealous Comedy, ${ }^{105}$ 'of which (be it admitted), we know nothing save that they [the company to which Shakespeare belonged] had performed it on 5 January, 1593; and turned Shakespeare upon it to work it up;' and that this comedy 'contained some topical fooling on Count Mümpellgart and a "borrowing" of horses'. It might also have contained a comic

108 See Lea, op. cit., ii, p. 591.

103 Printed in Johnson and Steevens' Shakespeare (1778), p. 250, and in Malone's Shakespeare (1821). The books which specifically deal with Shakespeare's characters have very little to say about Dr. Caius, except Cumberland Clark, Shakespeare and National Character (1934,) who declines to accept any identification with Dr. Caius of Cambridge.

104 P. xxii.

105 Chambers, Elizabethan Stage, ii, pp. 123, 130, 201. 
Lord McNair, Q.C.

French doctor. It is also possible that the character who ultimately became Dr. Caius was originally not a doctor at all but something else.

On the subject of Dr. Caius he said:106

We can make nothing of the attempts to identify him with Dr. John Caius, re-founder of a very famous house of learning now known as Gonville and Caius College, Cambridge. That eminent physician and anatomist (1510-1573) was an Englishman born and bred-'Caius' being but a Latinised form of 'Keys' or 'Kees' - and there is nothing to connect him with the French doctor in our play save (if it be remarkable of that age) an antipathy to Welshmen suggested in one of the College Statutes and long since corrected. But he had been the most renowned physician of his time, and court attendant upon three sovereigns, Edward VI, Mary, and Elizabeth herself. So here comes in the puzzle, which we can only state and leave, with no pretence at being able to solve it. The 'French doctor' may have been a fashionable butt on the boards: he reappears in The Return from Parnassus; and Steevens cites, from Jack of Dover's Quest of Inquirie (1604), a tale entitled 'The Foole of Winsor' and beginning: 'Upon a time, there was in Winsor (quoth another of the jurie) a certaine simple outlandish doctor of phisicke, belonging to the Deane, who on a day being at Eton College... 'But how did Shakespeare dare to employ, in the Queen's own presence, the name of 'Caius' for his invented figure of fun? We can only suggest that there was a French quack-doctor at Windsor in 1598: and that Shakespeare, caricaturing him 'to the life,' by a most audacious stroke of metonymy called him by the name of that revered predecessor whom he least resembled.' And on p. 106 ... 'It is conceivable that the character was intended as a caricature of the Englishman in an earlier draft of the play and that he was converted into a Frenchman in a subsequent revision. But cf. p. xxxiii.

As Dover Wilson has pointed out, ${ }^{107}$ our suspicions concerning the origin of the character called Dr. Caius must be aroused by the fact that in the Quarto of The Merry Wives Mrs. Quickly tells Simple to 'step into the Counting-house' of Dr. Caius, which in the Folio becomes 'goe into this Closset', and Dr. Caius himself in the Quarto refers to his 'Counting-house'. What is a medical doctor doing with a counting-house?-a word which suggests the business of a merchant or a moneylender? Shylock does not have a counting-house, but no one would be surprised if he did, as Marlowe's Jew of Malta did. And why does Dr. Caius tell his servant Rugby to look out 'ore de stall'?

Dr. Poynter in Shakespeare Survey $17^{108}$ has written: 'Shakespeare's Dr. Caius has no resemblance to the serious and scholarly John Caius who was President of the College of Physicians. However, considering the limitations of the physician's practical abilities, his prized latinity and his pompous bearing, it is perhaps not unnatural that he should be made the butt of comedy'. ${ }^{109}$

106 Pp. xxxiii-xxxiv.

107 Introduction, p. Xxiii and p. 106: 'It is conceivable that the character was intended as a caricature of the Englishman, i.e. Dr. Caius, in an earlier draft of the play and that he was converted into a Frenchman in a subsequent revision'.

108 At. p. 157.

100 Citing C. J. Sisson in 'Shakespeare's Helena and Dr. William Harvey', Essays and Studies, (1960) pp. 1-20, who (op. cit. p. 11) suggests the original of Dr. Caius may have been the French-born Dr. Peter Chamberlain'. In the British Medical Journal, 1926, i, 670, St. Clair Thomson attacked the suggestion that the French (or possibly Swiss) physician Turquet de Mayerne is portrayed as Dr. Caius in The Merry Wives of Windsor; de Mayerne does not appear to have settled in England until 1611 (see D.N.B.). See also Rolleston, 'Some Worthies of the Cambridge Medical School', in Annals of Medical History, 1926, 8. As St. Clair Thomson says: 'It is unthinkable that Shakespeare intended to portray in the figure of fun dubbed Dr. Caius in The Merry Wives of Windsor the learned and dignified president of the College of Physicians'. In 1964 Dr. Poynter prepared for exhibition at the Wellcome Historical Medical Museum under the title "Medicine and Health in Shakepeare's Time' a Note and Catalogue of the numerous treatises then available; and see Copeman, Doctors and Diseases in Tudor Times, Ch. III. 


\section{Why is the Doctor in 'The Merry Wives of Windsor' called Caius?}

I should add that Professor Bradbrook, influenced mainly I think by the fact of Dr. Caius' known dislike of the Welsh already mentioned, thinks that Shakespeare had in mind the real Dr. Caius.

In conclusion, I have the feeling that there is some mystery, some piece of information relevant to this enquiry which is still lacking. Perhaps some day copies of The Jealous Comedy and The French Doctor may be found and may yield up their secrets. Till then I doubt whether any further speculation is profitable, and I expect to remain content with the fourth explanation indicated above.

\section{APPENDIX}

Sur John Hall, médecin (et gendre de Shakespeare). -A-t-il étudié et pris des grades de médecine à Paris?

I.-De fait, les Commentarii ${ }^{1}$ de la Faculté de médecine, qui relatent les examens dont les épreuves permettaient d'obtenir des grades en médecine, ne mentionnent pas le nom de John Hall entre 1597 et 1607. Pour les 3 types d'épreuves (Quodlibétaires, Cardinales, Postilliaires), le nombre des candidats est d'ailleurs très peu élevé. Ce qui donne à penser qu'il y avait aux cours de Faculté beaucoup d'auditeurs libres. Aucun registre d'inscriptions n'a été conservé avant le milieu du XVIII ${ }^{\circ}$ s. Il faut donc envisager la possibilité d'acquérir la compétence médicale à la Faculté, sans s'y faire conférer de grades.

Or, on pouvait suivre, à Paris, des cours de médecine hors Faculté. D'abord, au Collège de France, où la chaire de médecine était très ancienne. Il y eut 4 titulaires pour la période 1557-1607; en fait, c'étaient des professeurs de Faculté qui enseignaient et, probablement, pour des étudiants non débutants, mais déjà avancés dans leurs études. Des cours de médecine libres existaient dans certains collèges. Ces collèges conféraient-ils des grades? La recherche reste à faire.

II.-Pour John Hall, la question se pose un peu différement, car il est anglais et très probablement protestant. Comme tel, quel peut être son régime d'études à Paris?

$\mathrm{Si}$, à cause de l'Edit de Nantes, la Faculté de Médecine ne pouvait interdire aux protestants de suivre les cours ni peut-être même de postuler les grades, elle mettait aux examens des conditions telles-la teneur du serment exigé avant la collation du grade de bachelier qu'en fait nul protestant ne pouvait s'y graduer. Sans doute pouvait-il se faire graduer ailleurs, mais la recherche paraît entièrement à faire.

Anglais, John Hall a da s'agréger tout de suite à la 'nation d'Angleterre et d'Allemagne', dont il nous reste des archives (Registres des Procureurs, ${ }^{2}$ Registres des Receveurs ${ }^{8}$ conservés aujourd'hui aux Archives nationales). Un dépouillement long et assez ardu serait nécessaire pour découvrir éventuellement son nom. On aura plus de chance de la trouver dans des documents financiers que dans des documents plus juridiques.

Bref, la difficulté est grande de trouver trace des simples étudiants quand ils n'ont pas quelque fonction officielle au sein de leur nation ou dans l'Université (par exemple comme répétiteurs).

Pierre Timbal.

${ }^{1}$ La série est complète de la fin du XIV• à la fin du XVIII• s.; elle est toujours conservée à la Faculté de médecine.

2 Pour les dates envisagees: H 2589 (1552-1613), dit aussi 'conclusions'.

Id.: H 2590 (1544-1609). 